\title{
Measurement of Flux at Sediment-Water Interface Using a Seepage Meter under Controlled Flow Conditions
}

\author{
Changyong Lee ${ }^{1,2}$, Wonbin $\operatorname{Kim}^{1,3}$ and Sung-Wook Jeen $1,4, *$ (D) \\ 1 Department of Earth and Environmental Sciences \& The Earth and Environmental Science System Research \\ Center, Jeonbuk National University, Jeonju-si 54896, Korea; lcy0712@kaeri.re.kr (C.L.); \\ onebean@kigam.re.kr (W.K.) \\ 2 Radioactive Waste Disposal Research Division, Korea Atomic Energy Research Institute (KAERI), \\ Daejeon 34057, Korea \\ 3 Groundwater Department, Geologic Environment Division, Korea Institute of Geoscience and Mineral \\ Resources (KIGAM), Daejeon 34132, Korea \\ 4 Department of Environment and Energy, Jeonbuk National University, Jeonju-si 54896, Korea \\ * Correspondence: sjeen@jbnu.ac.kr; Tel.: +82-(63)-270-3429; Fax: +82-(63)-270-3399
}

Received: 29 September 2020; Accepted: 30 October 2020; Published: 2 November 2020

check for updates

\begin{abstract}
The accuracy of groundwater flux measurement using a seepage meter was evaluated through a series of laboratory experiments under controlled flow conditions. Simulated groundwater influx and outflux rates were measured using a seepage meter, and the results were compared with the known water flux rates in our controlled tank flow system. Differences induced by the use of two different types of collection bag (Types 1 and 2) were also evaluated. The slopes of the trend lines between the controlled influx rate and influx as measured by the seepage meter were 0.6669 (for Type $1 \mathrm{bag}$ ) and 0.8563 (for Type $2 \mathrm{bag}$ ), suggesting that the groundwater influx rate as measured by the seepage meter may be less than the actual rate. This may be due to the resistance of the collection bags and head loss induced at the tubing orifice. With respect to outflux measurement, the slopes of the trend line were 1.3534 (for Type 1 bags) and 1.4748 (for Type 2 bags), suggesting that the outflux rate as measured by the seepage meter may be more than the actual rate. The size and wall thickness of the collection bag used affected the measured flux rates. This study suggests that, as long as errors can be identified, seepage meters can be a reliable means of studying groundwater-surface water interactions.
\end{abstract}

Keywords: groundwater; surface water; interaction; seepage meter; controlled experiment

\section{Introduction}

Groundwater and surface water interact across a variety of topographic and climate environments and they support aquatic ecosystems [1,2]. From the perspective of the water cycle, surface water bodies are essentially an integral part of the groundwater system. With respect to river systems, there are two types of interaction between groundwater and surface water: the 'gaining stream' through which groundwater flows into surface water, and the 'losing stream' through which surface water flows into groundwater [3]. If either the groundwater or surface water is developed or becomes contaminated, it can affect each other [4]. Therefore, it is essential to understand the relationship between groundwater and surface water in order to effectively manage water resources $[5,6]$.

A number of methods have been used to evaluate interactions between groundwater and surface water, including hydraulic, numerical, thermal, isotopic, biological, and hydrogeochemical methods. One method that relies on the hydraulic gradient between groundwater and surface water levels, 
hydraulic conductivity of an aquifer, and Darcy's law can calculate groundwater influx/outflux relatively simply $[7,8]$. However, obtaining accurate values of the hydraulic gradient and hydraulic conductivity is very difficult. While numerical modeling based on groundwater flow equation have been used to evaluate the contribution of groundwater to surface water $[9,10]$, there are uncertainties related to the simplified conceptual models for water systems and model parameters involved.

Methods using the temperature difference between groundwater and surface water are relatively cheap and robust [11-13]; however, they require analytical or numerical calculations based on thermal transport or thermal balance equations. While isotopic hydrograph separations are frequently used to evaluate the contribution of groundwater to surface water $[14,15]$, this method requires assumptions about two-component or three-component systems. It is also essential to define accurate end-members when calculating mixing ratios. Analysis of microorganisms in riparian zones is used to differentiate whether the area is under the influence of groundwater or surface water $[16,17]$. There have also been efforts to combine geochemical characteristics with analyses from water level, temperature, isotopes, microorganisms, and statistics to have integrated interpretation $[8,18]$.

While each of these methods has its own strengths and weaknesses, they are not methods to directly measure the groundwater flux. To date, the only means of directly quantifying the exchange of groundwater and surface water across the sediment-water interface is to use seepage meters [19]. The use of seepage meters to measure groundwater influx/outflux in the shallow groundwater-surface water interface was first proposed by Lee [20]. Although seepage meters, by virtue of their limited measuring area, may reflect the situation in only a limited portion of the interface, they directly measure the actual groundwater flux, and are accordingly considered among the most reliable methods. Seepage meters have been used in many studies to determine groundwater-surface water interaction, and are often used to calibrate or compare the effectiveness of other methods [21-28]. Most recently, Cremeans et al. [29] compared four tools for estimating groundwater-surface water exchanges, i.e., mini-piezometer, streambed point velocity probes (SBPVPs), temperature profiler, and seepage meters, in Grindsted $\AA$ (stream), Denmark, and showed that SBPVPs and seepage meters achieved least variability. Kim et al. [30] investigated groundwater-surface water interaction using seepage meters for the first time in Antarctica. A very good summary of history and evolution of seepage meters is provided in Rosenberry et al. [19].

Because a seepage meter directly measures groundwater flux and the measured groundwater flux should represent an accurate value at the measuring point, determining the accuracy of the measurement and errors induced by experimental factors is important. Although the principle by which seepage meters operate seems relatively simple, their performance is far from simple. Murdoch and Kelly [31] suggested that the magnitude of the measurement error depends on the conductance of the bag, the geometry of the collection pan, and the hydraulic conductivity of the bed sediments. In streams in particular, a current that flows over the collection bag may affect the hydraulic head in the bag or distort the bag, and lead to decreased or increased flux measured by the seepage meter [31]. Rosenberry and Pitlick [32] suggested that measurement errors can be introduced by improper seepage meter installation or deployment.

A number of studies have evaluated the accuracy of seepage meter measurement. For example, Shaw and Prepas [33] studied the errors that can be induced by a collection bag when it is naturally inflated during the influx of water, showing that anomalous short-term influxes of water into the plastic bags can occur after they are attached to the seepage meter. Belanger and Montgomery [34] suggested that measurement errors may result from flow field deflection, frictional resistance, and head losses within the meter and prefilled bags. Libelo and MacIntyre [35] indicated that surface flow across the seepage meter alters the hydraulic head within the meter and induces augmented seepage flow, resulting in variation in the measured flow rates. These studies are valuable, but studies that have evaluated the accuracy of both influx and outflux measurement under controlled laboratory conditions have been rare. 
In this study, we tested whether a seepage meter can accurately measure known fluxes of groundwater under controlled flow conditions. A water tank capable of controlling the flux rate of water was built and a seepage meter was installed in the tank. Experiments were conducted to compare the flux rates measured by the seepage meter against the actual fluxes of water entering and leaving the tank. Influx measurement experiments were conducted at fixed flow rates controlled by constant head conditions. Outflux rates were also experimentally measured, with flux rates controlled by pumping water at particular rates. In addition, differences in the flow rates using two different types of collection bag were compared. This study can, therefore, be used to determine the applicability and usefulness of seepage meters to the study of the interactions between groundwater and surface water. In particular, with the limited studies to date on the accuracy of outflux measurement, this study provides a systematic evaluation regarding the accuracy of both influx and outflux measurements in a range of controlled flow rates under the same experimental conditions.

\section{Experimental Methods}

A seepage meter was set up in the laboratory so that the meter could be isolated from external factors, including precipitation, evaporation, and other dynamic shifts inherent to real-world water systems. A water tank capable of accurately controlling the influx and outflux of water was required so that the amount of water entering and leaving the seepage meter could be measured. The flux rate of water in the tank was measured against that measured by the seepage meter as a means of testing the accuracy of the seepage meter. We also tested whether the measurement changed if the type of collection bag used in the seepage meter changed.

\subsection{Seepage Meter}

The seepage meter used in this experiment was manufactured by cutting a steel drum into a size of $25 \mathrm{~cm}$ in height and $58 \mathrm{~cm}$ in diameter. The bottom was open while the top was blocked. A hole with a diameter of $50 \mathrm{~mm}$ was made in the top, into which a rubber stopper connected to a collecting bag and the seepage meter entered. The rubber stopper with $50 \mathrm{~mm}$ in lower diameter and $55 \mathrm{~mm}$ in upper diameter was used in order to ensure a tight fit into the seepage meter. A polytetrafluoroethylene (PTFE) tube with an outer diameter of $10 \mathrm{~mm}$ and an inner diameter of $8 \mathrm{~mm}$ was inserted into the center of the rubber stopper to allow water to enter and exit the collection bag. This type of seepage meter was used for the field study of Kim et al. [36], which showed the effectiveness of the seepage meter to evaluate flux at groundwater-surface water interface in a small lake in Korea.

\subsection{Water Tank}

A cylindrical polyethylene (PE) water tank with a diameter of $132 \mathrm{~cm}$ and a height of $145 \mathrm{~cm}$ was used. In order to allow the influx and outflux of simulated groundwater through the tank, a pipe line was manufactured. The pipe was made of polyvinyl chloride (PVC) capable of withstanding great deal of pressure. The exterior of the pipe line located at the bottom of the tank was made into an octagonal shape using a pipe with a diameter of $50 \mathrm{~mm}$. The inside of the pipe was made into a square using a pipe with a diameter of $25 \mathrm{~mm}$. The empty space was connected into a ladder-shape to prevent water from concentrating in one place and to allow water to emerge from all points simultaneously to the degree possible (Figure 1a). Holes were drilled into the pipe so that water could come out of the pipe. The hole was covered with fine mesh plastic screen and attached to the pipe so that sand or geological materials could not enter and block the holes. 


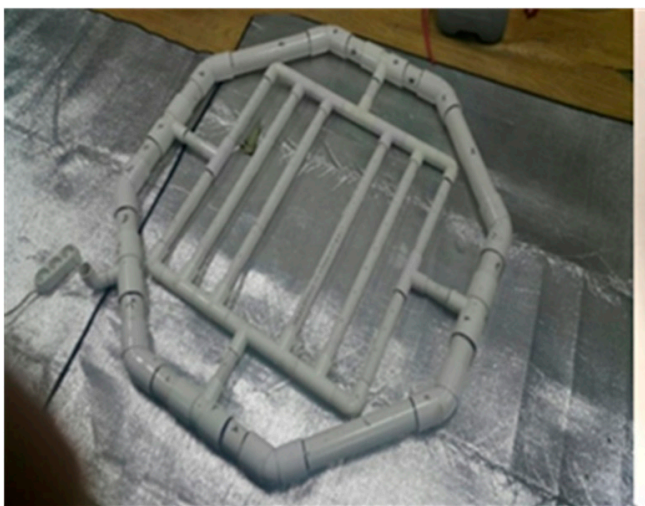

(a)

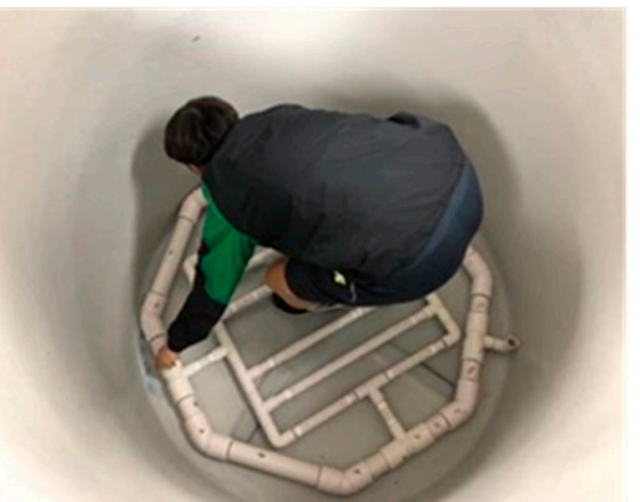

(b)

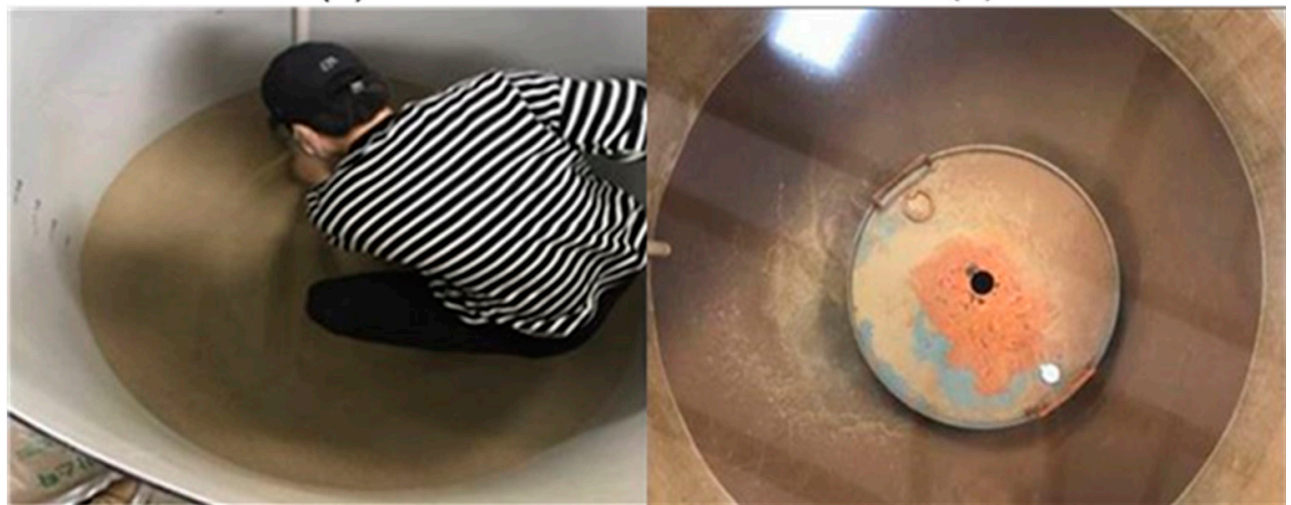

(c)

(d)

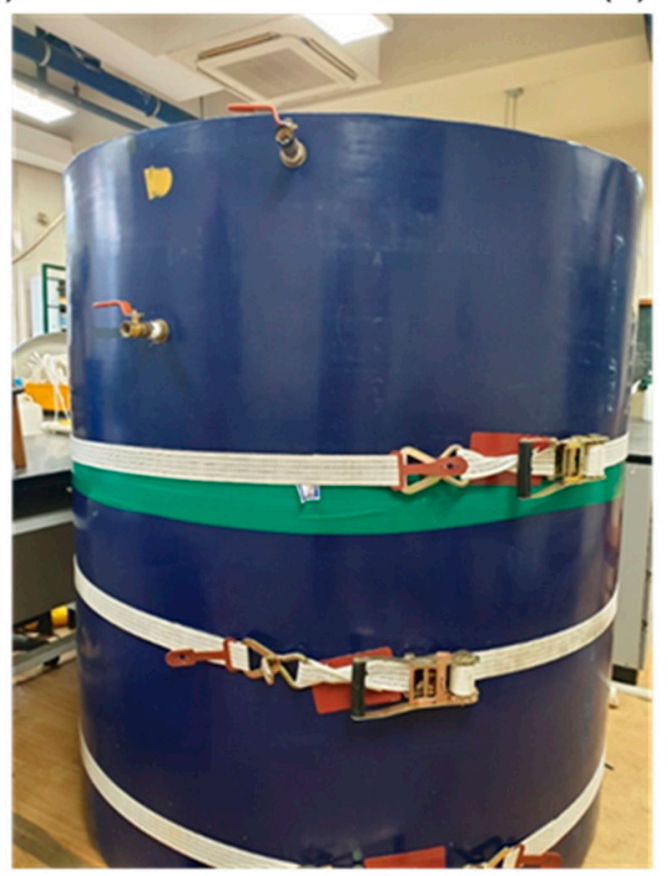

(e)

Figure 1. Water tank manufacturing processes: (a) manufacturing the pipe line on the bottom of the tank, (b) installation of the pipe line, (c) packing with sand and gravel, (d) installation of the seepage meter, and (e) completed set up of the water tank. The exterior of the tank was tightened with belts to prevent expansion of the tank resulting from sediment and water pressure. 
The manufactured pipe line was installed on the bottom of the water tank (Figure 1b). An additional vertical pipe was connected to the bottom pipe to supply water from a reservoir or to remove water using a peristaltic pump (Geopump; Geotech Environmental Equipment, Inc., Denver, CO, USA). Gravel was stacked over this at a height of $15 \mathrm{~cm}$, followed by sand at a height of $45 \mathrm{~cm}$, followed by sand sieved to $<2 \mathrm{~mm}$ at a height of $10 \mathrm{~cm}$, resulting in a total height of $70 \mathrm{~cm}$ (Figure 1c). The top level of sieved sand was intended to ensure even water flow into the seepage meter, as the top layer was in direct contact with the seepage meter.

Two valves were installed on the side of the tank to allow water to exit when the water level exceeded the height of the valves. The two valves were used to adjust the water level difference during the influx measurement experiments. Different flow rates were controlled by different water levels between the water reservoir and the valves on the side of the water tank. After checking to confirm that water flowed well through the pipe, water was filled up to the valve level of the water tank and a seepage meter was installed in the center of the top layer (Figure 1d). As there was a risk of expansion of the tank due to a large amount of sediment and water inside the tank, the exterior of the tank was tightened with belts (Figure 1e). Finally, the water reservoir was installed outside the tank, and the pipe line was connected so that water could enter or exit the tank. After the completion of the tank flow system, the seepage meter remained in place for a few weeks before the start of the experiments to help settlement of the sediment.

\subsection{Collection Bags}

Influx and outflux measurement experiments were each conducted using two types of bag (Table 1). The two bags tested differed in size, material, and closing method. The Type 1 collection bag was made of PE material, approximately $25 \mathrm{~cm} \times 35 \mathrm{~cm}$ large, and with a maximum capacity of approximately $4.4 \pm 0.2 \mathrm{~L}$. This collection bag was shaped like an envelope with a string such that the bag could be closed by tightening the string. The Type 2 collection bag was made of low density polyethylene (LDPE) and linear low density polyethylene (LLDPE), and was approximately $33 \mathrm{~cm} \times 38.1 \mathrm{~cm}$ in size, with a maximum capacity of approximately $6.7 \pm 0.3 \mathrm{~L}$. The Type 2 bag had a zipper at the entrance of the envelope. When connected to the tube of the rubber stopper on the top of the seepage meter, the entrance of the envelope was open a bit, while the remainder of the entrance was taped to ensure no leakage. The tightness of the prepared bag was tested overnight with some water filled and located inside a small water tank. By measuring the weights of the bag between the times, it was confirmed that there was no difference in the bag weight and thus no leak. The wall thicknesses of each of the collection bags was measured with a digital caliper (CD-30C; Mitutoyo, Kawasaki, Japan) at 0.07 and $0.05 \mathrm{~mm}$, for the Type 1 and 2 collection bags, respectively.

Table 1. Collection bag specifications.

\begin{tabular}{|c|c|c|}
\hline & Type 1 & Type 2 \\
\hline Size & $25 \mathrm{~cm} \times 35 \mathrm{~cm}$ & $33 \mathrm{~cm} \times 38.1 \mathrm{~cm}$ \\
\hline Wall thickness & $0.07 \mathrm{~mm}$ & $0.05 \mathrm{~mm}$ \\
\hline Volume & $4.4 \pm 0.2 \mathrm{~L}$ & $6.7 \pm 0.3 \mathrm{~L}$ \\
\hline Material & Polyethylene (PE) & $\begin{array}{l}\text { Low density polyethylene (LDPE), } \\
\text { liner low density polyethylene } \\
\text { (LLDPE) }\end{array}$ \\
\hline Brand name (manufacturer) & $\begin{array}{l}\text { Super Pack (Super Pack, } \\
\text { Seoul, Korea) }\end{array}$ & $\begin{array}{c}\text { Ziploc }^{\circledR} \text { (S.C. Johnson and Son, Inc., } \\
\text { Racine, WI, USA) }\end{array}$ \\
\hline
\end{tabular}

\subsection{Experimental Procedures}

The influx measurement experiment was modeled after the constant head permeability test [37] in order to maintain constant influx rates. A constant head permeability test determines the hydraulic conductivity of an aquifer material, by measuring the amount of water flowing through 
the cross-sectional area of a porous medium under a constant head difference. In this test, water was supplied to the tank while maintaining a constant water level difference, and the flux rate was measured after a period of time.

In order to compare the measured flux rate (total flux through the tank) with that measured by the seepage meter, each flux rate was converted to the flux rate per unit cross-sectional area. As per Figure 2, the flux rate $\left(Q_{s}\right)$ obtained by the seepage meter was a fraction of the simulated groundwater flux through the entire surface of the sediment contained in the tank $\left(Q_{t}\right)$. In theory, the flux measured by the seepage meter divided by the cross-sectional area of the seepage meter $\left(\mathrm{A}_{\mathrm{s}}\right)$ should be identical to the flux rate through the entire tank divided by the cross-sectional area of the $\operatorname{tank}\left(A_{t}\right)$, assuming homogeneity of specific flux across the sediment surface. The resulting normalized flux per unit surface area (q) is also known as specific discharge/flux or Darcy flux. The "flux" in this paper hereafter is referred to this specific flux, and $Q_{t} / A_{t}\left(q_{t}\right)$ and $Q_{s} / A_{s}\left(q_{s}\right)$ are referred to "tank specific flux" and "seepage specific flux", respectively.

$$
\frac{Q_{s}}{A_{s}}=\frac{Q_{t}}{A_{t}}
$$

where
$\mathrm{A}_{\mathrm{s}}=$ Cross-sectional area of the seepage meter $\left(\mathrm{m}^{2}\right)$
$A_{t}=$ Cross-sectional area of the sediment (tank) $\left(\mathrm{m}^{2}\right)$
$\mathrm{Q}_{\mathrm{s}}=$ Flux through the seepage meter $\left(\mathrm{m}^{3} / \mathrm{s}\right)$
$\mathrm{Q}_{\mathrm{t}}=$ Flux through the sediment $(\operatorname{tank})\left(\mathrm{m}^{3} / \mathrm{s}\right)$

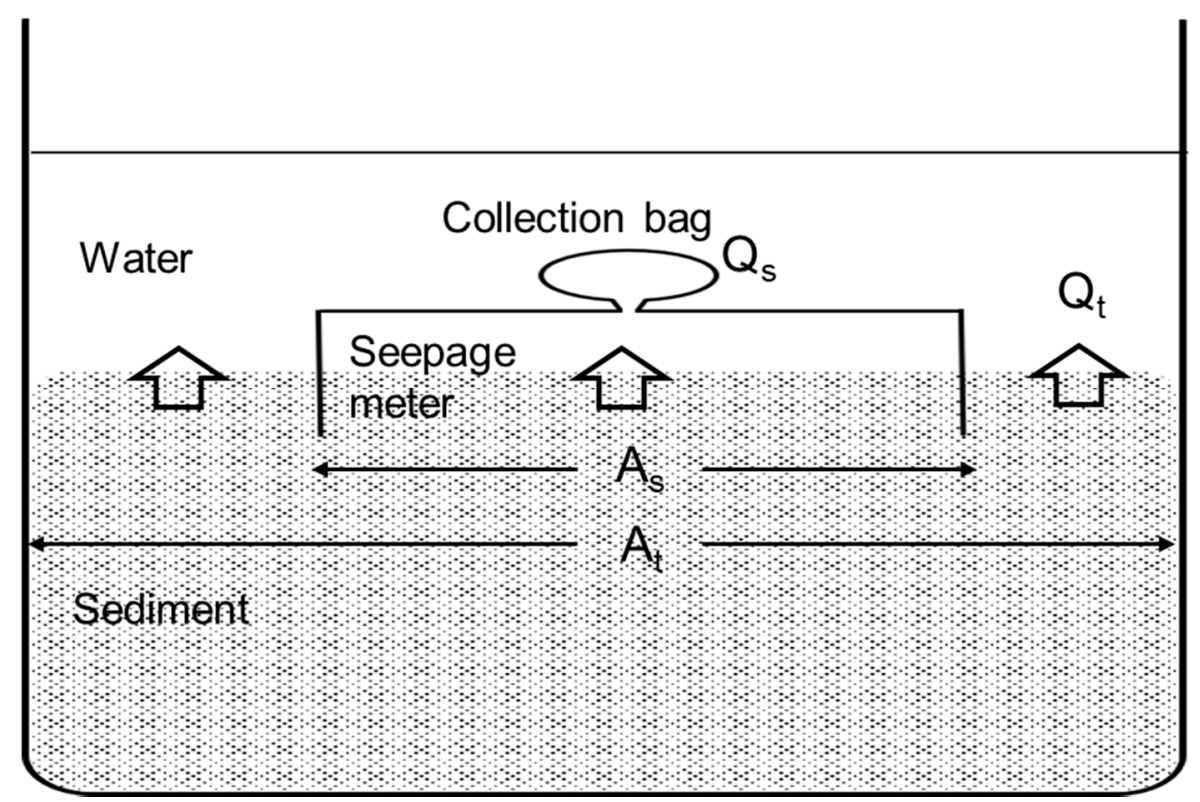

Figure 2. Relationship between the flux through the sediment in the tank and the flux measured by the seepage meter.

Figure $3 \mathrm{a}$ is a schematic diagram for the influx measurement experiment. In this experiment, water was supplied to the tank from the water reservoir where water was continuously supplied by the peristaltic pump, while excess water overflowed the reservoir, thereby maintaining a constant water level difference. The water from the reservoir flowed into the pipeline at the bottom of the tank via the vertical pipe. Water emerged from the valve was collected into a bucket and measured. The water level difference was determined by measuring the height of the valve on the side of the tank and that of the water reservoir. The water level differences $(\Delta \mathrm{h}$; Figure 3a) used for the experiments were $20 \mathrm{~cm}$, $40 \mathrm{~cm}, 60 \mathrm{~cm}, 80 \mathrm{~cm}$, and $100 \mathrm{~cm}$. 


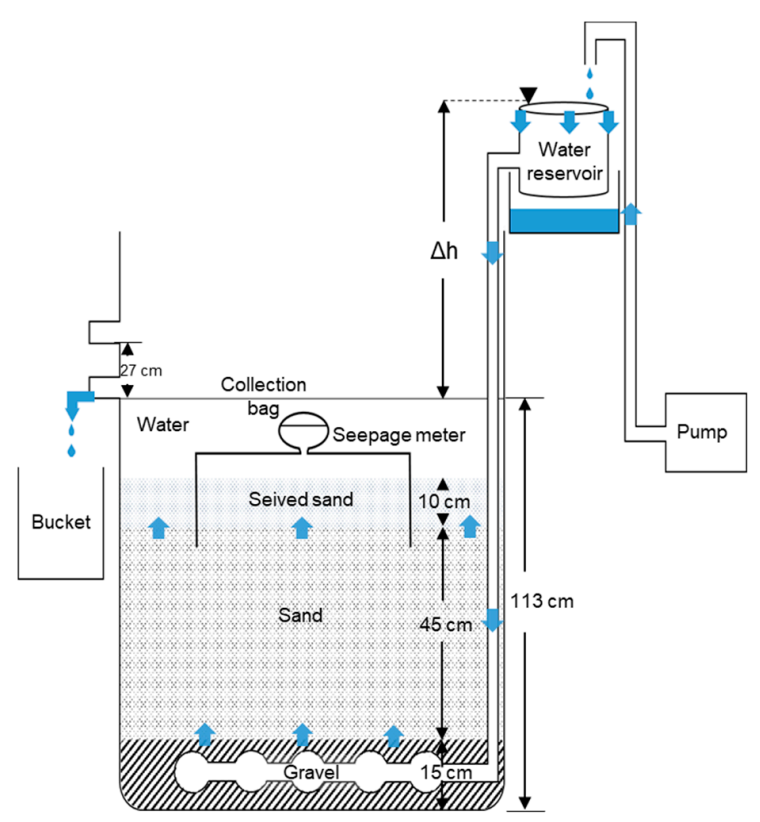

(a)

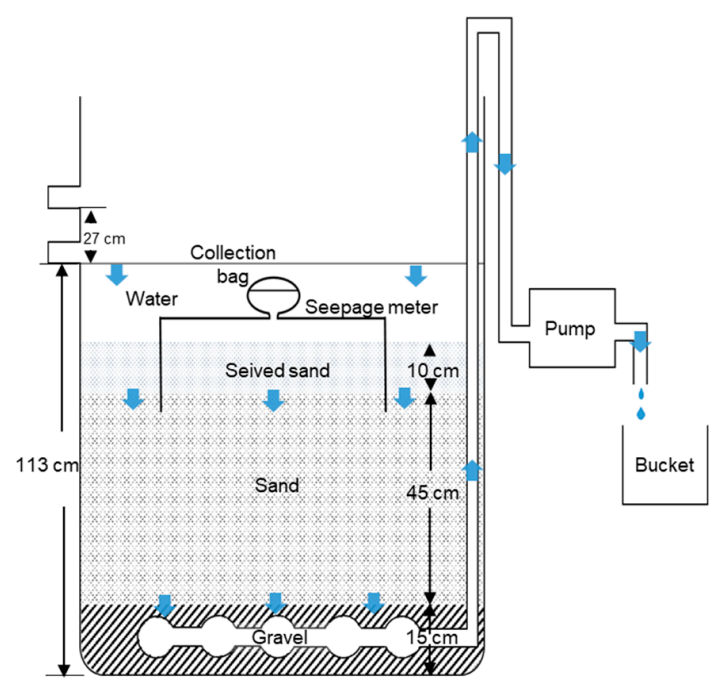

(b)

Figure 3. Schematics of (a) the influx measurement experiment and (b) the outflux measurement experiment.

The influx measurement experiment was divided into two steps. First, the influx rate without a collection bag was measured at each water level difference to determine how much water flowed in the tank at each water level difference. The amount of water exiting the tank's side valve was measured and calculated as a flux rate by divided by the cross-sectional area of the tank and the measurement time. Second, we checked how much water actually entered the seepage meter by installing the collection bag under the same water level difference as that used in the first step. After a period of time, the amount of water collected in the bag and the amount of water that exited through the valve were measured. These two values were added together to calculate the total flux rate. The volume of water was measured using an $1 \mathrm{~L}( \pm 8 \mathrm{~mL})$ graduated cylinder. The influx measurement experiment started with empty collection bags because the bag had a limited capacity to cover the entire range of head difference. Experiment time of one hour for the head differences of $20 \mathrm{~cm}, 40 \mathrm{~cm}$, and $60 \mathrm{~cm}$ and $30 \mathrm{~min}$ for $80 \mathrm{~cm}$ and $100 \mathrm{~cm}$ was used for one measurement of influx rate. For the influx measurement experiments with the Type 1 collection bag, five experiments were repeated at each water level difference (Table 2). Likewise, five experiments were repeated at each water level with the Type 2 collection bag. An additional three experiments were conducted at water level differences of $80 \mathrm{~cm}$ and $100 \mathrm{~cm}$ for cases where the collection bag was inserted into the seepage meter (Table 3). 
Table 2. Influx measurement experiment using the Type 1 collection bag.

\begin{tabular}{|c|c|c|c|c|c|c|c|c|c|c|c|c|c|c|c|}
\hline & \multicolumn{15}{|c|}{ Head Difference } \\
\hline & \multicolumn{3}{|c|}{$20 \mathrm{~cm}$} & \multicolumn{3}{|c|}{$40 \mathrm{~cm}$} & \multicolumn{3}{|c|}{$60 \mathrm{~cm}$} & \multicolumn{3}{|c|}{$80 \mathrm{~cm}$} & \multicolumn{3}{|c|}{$100 \mathrm{~cm}$} \\
\hline & No Bag & With & Bag & No Bag & With & Bag & No Bag & With & Bag & No Bag & With & Bag & No Bag & With & Bag \\
\hline $\begin{array}{c}\text { Experiment } \\
\text { No. }\end{array}$ & $\begin{array}{c}\text { Tank } \\
\text { Specific } \\
\text { Flux } \\
\left(\times 10^{-6}\right. \\
\text { m/s })\end{array}$ & $\begin{array}{c}\text { Tank } \\
\text { Specific } \\
\text { Flux } \\
\left(\times 10^{-6}\right. \\
\text { m/s })\end{array}$ & $\begin{array}{c}\text { Seepage } \\
\text { Specific } \\
\text { Flux } \\
\left(\times 10^{-6}\right. \\
\mathrm{m} / \mathrm{s})\end{array}$ & $\begin{array}{c}\text { Tank } \\
\text { Specific } \\
\text { Flux } \\
\left(\times 10^{-6}\right. \\
\mathrm{m} / \mathrm{s})\end{array}$ & $\begin{array}{c}\text { Tank } \\
\text { Specific } \\
\text { Flux } \\
\left(\times 10^{-6}\right. \\
\text { m/s) }\end{array}$ & $\begin{array}{c}\text { Seepage } \\
\text { Specific } \\
\text { Flux } \\
\left(\times 10^{-6}\right. \\
\mathrm{m} / \mathrm{s})\end{array}$ & $\begin{array}{c}\text { Tank } \\
\text { Specific } \\
\text { Flux } \\
\left(\times 10^{-6}\right. \\
\text { m/s })\end{array}$ & $\begin{array}{c}\text { Tank } \\
\text { Specific } \\
\text { Flux } \\
\left(\times 10^{-6}\right. \\
\text { m/s })\end{array}$ & $\begin{array}{c}\text { Seepage } \\
\text { Specific } \\
\text { Flux } \\
\left(\times 10^{-6}\right. \\
\mathrm{m} / \mathrm{s})\end{array}$ & $\begin{array}{c}\text { Tank } \\
\text { Specific } \\
\text { Flux } \\
\left(\times 10^{-6}\right. \\
\mathrm{m} / \mathrm{s})\end{array}$ & $\begin{array}{c}\text { Tank } \\
\text { Specific } \\
\text { Flux } \\
\left(\times 10^{-6}\right. \\
\text { m/s })\end{array}$ & $\begin{array}{c}\text { Seepage } \\
\text { Specific } \\
\text { Flux } \\
\left(\times 10^{-6}\right. \\
\mathrm{m} / \mathrm{s})\end{array}$ & $\begin{array}{c}\text { Tank } \\
\text { Specific } \\
\text { Flux } \\
\left(\times 10^{-6}\right. \\
\text { m/s })\end{array}$ & $\begin{array}{c}\text { Tank } \\
\text { Specific } \\
\text { Flux } \\
\left(\times 10^{-6}\right. \\
\text { m/s })\end{array}$ & $\begin{array}{c}\text { Seepage } \\
\text { Specific } \\
\text { Flux } \\
\left(\times \mathbf{1 0}^{-6}\right. \\
\mathrm{m} / \mathrm{s})\end{array}$ \\
\hline 1st & 1.59 & 1.79 & 1.25 & 2.93 & 2.56 & 1.62 & 3.47 & 3.48 & 1.77 & 4.61 & 3.98 & 2.69 & 4.91 & 4.53 & 4.00 \\
\hline 2nd & & & & & & & & & & & & & & 4.8 & 3.81 \\
\hline $3 r d$ & 1.53 & & & 2.71 & & 1.5 & & & 2.2 & 4.4 & 4.2 & 2.9 & 4.7 & 4.7 & 3.20 \\
\hline 4th & & & & & & 2.04 & & & 1.91 & 4.5 & 4.03 & 2.96 & 4.66 & 4.77 & 3.26 \\
\hline 5th & 1.57 & 1.55 & 1.34 & 2.84 & 2.48 & 1.58 & 3.34 & 3.54 & 2.65 & 4.46 & 4.15 & 2.99 & 4.96 & 4.77 & 3.30 \\
\hline $\begin{array}{l}\text { Average } \\
\text { (standard } \\
\text { deviation) }\end{array}$ & $\begin{array}{c}1.60 \\
( \pm 0.06)\end{array}$ & $\begin{array}{c}1.61 \\
( \pm 0.10)\end{array}$ & $\begin{array}{c}1.27 \\
( \pm 0.04)\end{array}$ & $\begin{array}{c}2.82 \\
( \pm 0.09)\end{array}$ & $\begin{array}{c}2.51 \\
( \pm 0.06)\end{array}$ & $\begin{array}{c}1.69 \\
( \pm 0.20)\end{array}$ & $\begin{array}{c}3.48 \\
( \pm 0.12)\end{array}$ & $\begin{array}{c}3.52 \\
( \pm 0.03)\end{array}$ & $\begin{array}{c}2.09 \\
( \pm 0.36)\end{array}$ & $\begin{array}{c}4.54 \\
( \pm 0.07)\end{array}$ & $\begin{array}{c}4.11 \\
( \pm 0.11)\end{array}$ & $\begin{array}{c}2.91 \\
( \pm 0.13)\end{array}$ & $\begin{array}{c}4.79 \\
( \pm 0.14)\end{array}$ & $\begin{array}{c}4.74 \\
( \pm 0.12)\end{array}$ & $\begin{array}{c}3.51 \\
( \pm 0.36)\end{array}$ \\
\hline
\end{tabular}

Table 3. Influx measurement experiment using the Type 2 collection bag.

\begin{tabular}{|c|c|c|c|c|c|c|c|c|c|c|c|c|c|c|c|}
\hline & \multicolumn{15}{|c|}{ Head Difference } \\
\hline & \multicolumn{3}{|c|}{$20 \mathrm{~cm}$} & \multicolumn{3}{|c|}{$40 \mathrm{~cm}$} & \multicolumn{3}{|c|}{$60 \mathrm{~cm}$} & \multicolumn{3}{|c|}{$80 \mathrm{~cm}$} & \multicolumn{3}{|c|}{$100 \mathrm{~cm}$} \\
\hline & \multirow[b]{2}{*}{$\begin{array}{c}\text { No Bag } \\
\text { Tank } \\
\text { Specific } \\
\text { Flux } \\
\left(\times \mathbf{1 0}^{-6}\right. \\
\mathrm{m} / \mathrm{s})\end{array}$} & \multicolumn{2}{|c|}{ With Bag } & \multirow[b]{2}{*}{$\begin{array}{c}\text { No Bag } \\
\text { Tank } \\
\text { Specific } \\
\text { Flux } \\
\left(\times \mathbf{1 0}^{-6}\right. \\
\text { m/s })\end{array}$} & \multicolumn{2}{|c|}{ With Bag } & \multirow[b]{2}{*}{$\begin{array}{c}\text { No Bag } \\
\text { Tank } \\
\text { Specific } \\
\text { Flux } \\
\left(\times 10^{-6}\right. \\
\mathrm{m} / \mathrm{s})\end{array}$} & \multicolumn{2}{|c|}{ With Bag } & \multirow[b]{2}{*}{$\begin{array}{c}\text { No Bag } \\
\text { Tank } \\
\text { Specific } \\
\text { Flux } \\
\left(\times 10^{-6}\right. \\
\text { m/s })\end{array}$} & \multicolumn{2}{|c|}{ With Bag } & \multirow[b]{2}{*}{$\begin{array}{c}\text { No Bag } \\
\text { Tank } \\
\text { Specific } \\
\text { Flux } \\
\left(\times \mathbf{1 0}^{-6}\right. \\
\text { m/s })\end{array}$} & \multicolumn{2}{|c|}{ With Bag } \\
\hline $\begin{array}{c}\text { Experiment } \\
\text { No. }\end{array}$ & & $\begin{array}{c}\text { Tank } \\
\text { Specific } \\
\text { Flux } \\
\left(\times 10^{-6}\right. \\
\mathrm{m} / \mathrm{s})\end{array}$ & $\begin{array}{c}\text { Seepage } \\
\text { Specific } \\
\text { Flux } \\
\left(\times 10^{-6}\right. \\
\mathrm{m} / \mathrm{s})\end{array}$ & & $\begin{array}{c}\text { Tank } \\
\text { Specific } \\
\text { Flux } \\
\left(\times 10^{-6}\right. \\
\mathrm{m} / \mathrm{s})\end{array}$ & $\begin{array}{c}\text { Seepage } \\
\text { Specific } \\
\text { Flux } \\
\left(\times 10^{-6}\right. \\
\mathrm{m} / \mathrm{s})\end{array}$ & & $\begin{array}{c}\text { Tank } \\
\text { Specific } \\
\text { Flux } \\
\left(\times 10^{-6}\right. \\
\mathrm{m} / \mathrm{s})\end{array}$ & $\begin{array}{c}\text { Seepage } \\
\text { Specific } \\
\text { Flux } \\
\left(\times 10^{-6}\right. \\
\mathrm{m} / \mathrm{s})\end{array}$ & & $\begin{array}{c}\text { Tank } \\
\text { Specific } \\
\text { Flux } \\
\left(\times 10^{-6}\right. \\
\mathrm{m} / \mathrm{s})\end{array}$ & $\begin{array}{c}\text { Seepage } \\
\text { Specific } \\
\text { Flux } \\
\left(\times 10^{-6}\right. \\
\mathrm{m} / \mathrm{s})\end{array}$ & & $\begin{array}{c}\text { Tank } \\
\text { Specific } \\
\text { Flux } \\
\left(\times 10^{-6}\right. \\
\mathrm{m} / \mathrm{s})\end{array}$ & $\begin{array}{c}\text { Seepage } \\
\text { Specific } \\
\text { Flux } \\
\left(\times 10^{-6}\right. \\
\text { m/s })\end{array}$ \\
\hline 1st & 5.50 & 5.47 & 4.72 & 7.37 & 7.28 & 5.97 & 7.68 & 7.73 & 6.42 & 8.25 & 7.89 & 6.83 & 9.44 & 9.12 & 8.43 \\
\hline 2nd & & & & & & & & & & & 7. & & 9.1. & & 35 \\
\hline $3 \mathrm{rd}$ & 5.54 & 5.4 & 5.05 & 7. & 7.33 & 5.99 & 7.73 & 7.61 & 6.22 & 8. & 7.87 & 6.7 & 9.12 & 9.00 & 8.41 \\
\hline 4th & & & 4.92 & & 7.27 & 5.77 & & & 6.29 & & 7.82 & & 9.10 & 9.14 & 8.54 \\
\hline 5th & 5.71 & 5.4 & 4.76 & 7.30 & 7.27 & 5.84 & 7.67 & 7.56 & 5.9 & 7.9 & 7.88 & 6. & 9.14 & 9.11 & 8.24 \\
\hline 6th & & $\mathrm{N} /$ & N/A & N/A & N/A & N/A & & N/A & $\mathrm{N} /$ & $\mathrm{N}$ & 7.88 & & N/A & 9.10 & 8.22 \\
\hline 7th & N/A & $\mathrm{N} /$ & N/A & $\mathrm{N}$ & N/A & N/A & & N/A & N/A & $\mathrm{N} /$ & 7.87 & 6.92 & N/A & 9.15 & 8.49 \\
\hline 8th & N/A & N/A & N/A & N/A & N/A & N/A & N/A & N/A & N/A & N/A & 7.81 & 6.81 & N/A & 9.17 & 8.52 \\
\hline $\begin{array}{c}\text { Average } \\
\text { (standard } \\
\text { deviation) }\end{array}$ & $\begin{array}{c}5.57 \\
( \pm 0.09)\end{array}$ & $\begin{array}{c}5.86 \\
( \pm 0.88)\end{array}$ & $\begin{array}{c}4.82 \\
( \pm 0.16)\end{array}$ & $\begin{array}{c}7.30 \\
( \pm 0.08)\end{array}$ & $\begin{array}{c}7.28 \\
( \pm 0.03)\end{array}$ & $\begin{array}{c}5.87 \\
( \pm 0.11)\end{array}$ & $\begin{array}{c}7.68 \\
( \pm 0.04)\end{array}$ & $\begin{array}{c}7.61 \\
( \pm 0.07)\end{array}$ & $\begin{array}{c}6.22 \\
( \pm 0.19)\end{array}$ & $\begin{array}{c}8.00 \\
( \pm 0.18)\end{array}$ & $\begin{array}{c}7.87 \\
( \pm 0.04)\end{array}$ & $\begin{array}{c}6.90 \\
( \pm 0.20)\end{array}$ & $\begin{array}{c}9.20 \\
( \pm 0.14)\end{array}$ & $\begin{array}{c}9.11 \\
( \pm 0.05)\end{array}$ & $\begin{array}{c}8.40 \\
( \pm 0.12)\end{array}$ \\
\hline
\end{tabular}

N/A: Not applicable. 
Figure $3 b$ is a schematic diagram for the outflux measurement experiment. This experiment was conducted by putting a hose connected to the peristaltic pump into the vertical pipe line and removing water at a designated flow rate. For each experiment with a certain outflux rate, water was filled up to the level of the valve before the experiment started. In the outflux measurement experiment, the speed of the pump was changed. The speeds of the pump had five stages, with the slowest speed being Speed 1 and the fastest being Speed 5. Prior to the experiment, $4 \mathrm{~L}$ of water was added to the collection bag, which was then connected to the seepage meter. The water removed by the pump was then collected in a bucket and the amount of water was measured. At the end of the experiment, the difference between the initial $4 \mathrm{~L}$ of water and the water remaining in the collection bag was calculated and expressed as the outflux rate by dividing with the cross-sectional area of the seepage meter and the experiment time.

Like the influx measurement experiment, the outflux measurement experiment was divided into two steps. First, an experiment was conducted to check whether the water tank and pumping system properly removed a known quantity of water by proceeding without a collection bag in the seepage meter. For the second part, a collection bag filled with $4 \mathrm{~L}$ of water was inserted into the seepage meter, and water was removed using the pump. The outflux measurement experiments with the Types 1 and 2 collection bags took around 15 and $10 \mathrm{~min}$, respectively. This was to ensure that the water level in the tank does not fall down below the collection bag and seepage meter. For the outflux measurement experiments with the Types 1 and 2 collection bags, five and eight experiments, respectively, were repeated at each pump speed (Tables 4 and 5). 
Table 4. Outflux measurement experiment using the Type 1 collection bag.

\begin{tabular}{|c|c|c|c|c|c|c|c|c|c|c|c|c|c|c|c|}
\hline & \multicolumn{15}{|c|}{ Pump Speed } \\
\hline & \multicolumn{3}{|c|}{ Speed 1} & \multicolumn{3}{|c|}{ Speed 2} & \multicolumn{3}{|c|}{ Speed 3} & \multicolumn{3}{|c|}{ Speed 4} & \multicolumn{3}{|c|}{ Speed 5} \\
\hline & No Bag & With & Bag & No Bag & With & Bag & No Bag & With & Bag & No Bag & Witl & Bag & No Bag & With & Bag \\
\hline $\begin{array}{l}\text { Experiment } \\
\text { No. }\end{array}$ & $\begin{array}{c}\text { Tank } \\
\text { Specific } \\
\text { Flux } \\
\left(\times 10^{-6}\right. \\
\mathrm{m} / \mathrm{s})\end{array}$ & $\begin{array}{c}\text { Tank } \\
\text { Specific } \\
\text { Flux } \\
\left(\times 10^{-6}\right. \\
\mathrm{m} / \mathrm{s})\end{array}$ & $\begin{array}{c}\text { Seepage } \\
\text { Specific } \\
\text { Flux } \\
\left(\times 10^{-6}\right. \\
\mathrm{m} / \mathrm{s})\end{array}$ & $\begin{array}{c}\text { Tank } \\
\text { Specific } \\
\text { Flux } \\
\left(\times 10^{-6}\right. \\
\text { m/s) }\end{array}$ & $\begin{array}{c}\text { Tank } \\
\text { Specific } \\
\text { Flux } \\
\left(\times 10^{-6}\right. \\
\mathrm{m} / \mathrm{s})\end{array}$ & $\begin{array}{c}\text { Seepage } \\
\text { Specific } \\
\text { Flux } \\
\left(\times 10^{-6}\right. \\
\mathrm{m} / \mathrm{s})\end{array}$ & $\begin{array}{c}\text { Tank } \\
\text { Specific } \\
\text { Flux } \\
\left(\times 10^{-6}\right. \\
\text { m/s })\end{array}$ & $\begin{array}{c}\text { Tank } \\
\text { Specific } \\
\text { Flux } \\
\left(\times 10^{-6}\right. \\
\mathrm{m} / \mathrm{s})\end{array}$ & $\begin{array}{c}\text { Seepage } \\
\text { Specific } \\
\text { Flux } \\
\left(\times 10^{-6}\right. \\
\mathrm{m} / \mathrm{s})\end{array}$ & $\begin{array}{c}\text { Tank } \\
\text { Specific } \\
\text { Flux } \\
\left(\times 10^{-6}\right. \\
\text { m/s) }\end{array}$ & $\begin{array}{c}\text { Tank } \\
\text { Specific } \\
\text { Flux } \\
\left(\times 10^{-6}\right. \\
\mathrm{m} / \mathrm{s})\end{array}$ & $\begin{array}{c}\text { Seepage } \\
\text { Specific } \\
\text { Flux } \\
\left(\times 10^{-6}\right. \\
\mathrm{m} / \mathrm{s})\end{array}$ & $\begin{array}{c}\text { Tank } \\
\text { Specific } \\
\text { Flux } \\
\left(\times 10^{-6}\right. \\
\mathrm{m} / \mathrm{s})\end{array}$ & $\begin{array}{c}\text { Tank } \\
\text { Specific } \\
\text { Flux } \\
\left(\times 10^{-6}\right. \\
\mathrm{m} / \mathrm{s})\end{array}$ & $\begin{array}{c}\text { Seepage } \\
\text { Specific } \\
\text { Flux } \\
\left(\times 10^{-6}\right. \\
\mathrm{m} / \mathrm{s})\end{array}$ \\
\hline $1 \mathrm{~s}$ & 3.69 & 3.24 & 3.81 & 4.16 & 4.17 & 5.34 & 4.99 & 4.75 & 6.14 & 5.44 & 5.49 & 7.99 & 6.14 & 5.94 & 8.41 \\
\hline 2nd & & & & & & & & & & & 5. & & 6.1 & 6.07 & 8.75 \\
\hline & & & & & & & & & & & & & & & \\
\hline 4th & 3.59 & & 4.12 & 4.22 & 4.17 & 5.43 & 4.99 & 4.81 & 6.88 & 5.5 & 5.52 & 8.12 & 6.28 & 6.12 & 8.66 \\
\hline 5th & 3.60 & 3.36 & 3.83 & 4.22 & 4.07 & 5.32 & 5.03 & 4.98 & 6.73 & 5.50 & 5.57 & 8.24 & 6.07 & 6.15 & 8.71 \\
\hline $\begin{array}{l}\text { Average } \\
\text { (standard } \\
\text { deviation) }\end{array}$ & $\begin{array}{c}3.62 \\
( \pm 0.04)\end{array}$ & $\begin{array}{c}3.29 \\
( \pm 0.10)\end{array}$ & $\begin{array}{c}3.89 \\
( \pm 0.13)\end{array}$ & $\begin{array}{c}4.21 \\
( \pm 0.03)\end{array}$ & $\begin{array}{c}4.11 \\
( \pm 0.06)\end{array}$ & $\begin{array}{c}5.35 \\
( \pm 0.05)\end{array}$ & $\begin{array}{c}5.02 \\
( \pm 0.03)\end{array}$ & $\begin{array}{c}4.88 \\
( \pm 0.10)\end{array}$ & $\begin{array}{c}6.61 \\
( \pm 0.30)\end{array}$ & $\begin{array}{c}5.49 \\
( \pm 0.03)\end{array}$ & $\begin{array}{c}5.49 \\
( \pm 0.08)\end{array}$ & $\begin{array}{c}8.18 \\
( \pm 0.14)\end{array}$ & $\begin{array}{c}6.13 \\
( \pm 0.09)\end{array}$ & $\begin{array}{c}6.11 \\
( \pm 0.10)\end{array}$ & $\begin{array}{c}8.62 \\
( \pm 0.13)\end{array}$ \\
\hline
\end{tabular}

Table 5. Outflux measurement experiment using the Type 2 collection bag.

\begin{tabular}{|c|c|c|c|c|c|c|c|c|c|c|c|c|c|c|c|}
\hline \multirow[b]{4}{*}{$\begin{array}{c}\text { Experiment } \\
\text { No. }\end{array}$} & \multicolumn{15}{|c|}{ Pump Speed } \\
\hline & \multicolumn{3}{|c|}{ Speed 1} & \multicolumn{3}{|c|}{ Speed 2} & \multicolumn{3}{|c|}{ Speed 3} & \multicolumn{3}{|c|}{ Speed 4} & \multicolumn{3}{|c|}{ Speed 5} \\
\hline & \multirow{2}{*}{$\begin{array}{c}\text { No Bag } \\
\text { Tank } \\
\text { Specific } \\
\text { Flux } \\
\left(\times 10^{-6}\right. \\
\text { m/s) }\end{array}$} & \multicolumn{2}{|c|}{ With Bag } & \multirow[b]{2}{*}{$\begin{array}{c}\text { No Bag } \\
\text { Tank } \\
\text { Specific } \\
\text { Flux } \\
\left(\times \mathbf{1 0}^{-6}\right. \\
\mathrm{m} / \mathrm{s})\end{array}$} & \multicolumn{2}{|c|}{ With Bag } & \multirow{2}{*}{$\begin{array}{c}\text { No Bag } \\
\text { Tank } \\
\text { Specific } \\
\text { Flux } \\
\left(\times 10^{-6}\right. \\
\text { m/s })\end{array}$} & \multicolumn{2}{|c|}{ With Bag } & \multirow[b]{2}{*}{$\begin{array}{c}\text { No Bag } \\
\text { Tank } \\
\text { Specific } \\
\text { Flux } \\
\left(\times 10^{-6}\right. \\
\text { m/s })\end{array}$} & \multicolumn{2}{|c|}{ With Bag } & \multirow[b]{2}{*}{$\begin{array}{c}\text { No Bag } \\
\text { Tank } \\
\text { Specific } \\
\text { Flux } \\
\left(\times 10^{-6}\right. \\
\text { m/s) }\end{array}$} & \multicolumn{2}{|c|}{ With Bag } \\
\hline & & $\begin{array}{c}\text { Tank } \\
\text { Specific } \\
\text { Flux } \\
\left(\times 10^{-6}\right. \\
\text { m/s) }\end{array}$ & $\begin{array}{c}\text { Seepage } \\
\text { Specific } \\
\text { Flux } \\
\left(\times 10^{-6}\right. \\
\mathrm{m} / \mathrm{s})\end{array}$ & & $\begin{array}{c}\text { Tank } \\
\text { Specific } \\
\text { Flux } \\
\left(\times 10^{-6}\right. \\
\text { m/s })\end{array}$ & $\begin{array}{c}\text { Seepage } \\
\text { Specific } \\
\text { Flux } \\
\left(\times 10^{-6}\right. \\
\mathrm{m} / \mathrm{s})\end{array}$ & & $\begin{array}{c}\text { Tank } \\
\text { Specific } \\
\text { Flux } \\
\left(\times 10^{-6}\right. \\
\mathrm{m} / \mathrm{s})\end{array}$ & $\begin{array}{c}\text { Seepage } \\
\text { Specific } \\
\text { Flux } \\
\left(\times 10^{-6}\right. \\
\mathrm{m} / \mathrm{s})\end{array}$ & & $\begin{array}{c}\text { Tank } \\
\text { Specific } \\
\text { Flux } \\
\left(\times 10^{-6}\right. \\
\mathrm{m} / \mathrm{s})\end{array}$ & $\begin{array}{c}\text { Seepage } \\
\text { Specific } \\
\text { Flux } \\
\left(\times 10^{-6}\right. \\
\mathrm{m} / \mathrm{s})\end{array}$ & & $\begin{array}{c}\text { Tank } \\
\text { Specific } \\
\text { Flux } \\
\left(\times 10^{-6}\right. \\
\mathrm{m} / \mathrm{s})\end{array}$ & $\begin{array}{c}\text { Seepage } \\
\text { Specific } \\
\text { Flux } \\
\left(\times 10^{-6}\right. \\
\text { m/s })\end{array}$ \\
\hline 1st & 3.80 & 3.73 & 7.25 & 4.85 & 4.75 & 8.14 & 6.07 & 5.66 & 8.14 & 7.10 & 6.71 & 10.5 & 7.50 & 7.94 & 11.5 \\
\hline 4th & 3.90 & 3.90 & 5.93 & 5.13 & 4.99 & 9.15 & 6.07 & 5.97 & 9.84 & 7.19 & 6.98 & 9.21 & 8.10 & 7.99 & 10.3 \\
\hline 5 th & 3.82 & 3.91 & 6.81 & 5.46 & 4.99 & 8.20 & 6.07 & 6.02 & 1.00 & 7.21 & 6.99 & 9.02 & 8.06 & 7.97 & 11.5 \\
\hline 6th & 3.92 & 3.95 & 7.32 & 5.18 & 4.99 & 8.96 & 6.11 & 6.08 & 9.34 & 7.16 & 6.94 & 9.21 & 8.31 & 8.06 & 11.7 \\
\hline 7th & 3.87 & 3.91 & 7.89 & 5.21 & 5.12 & 7.38 & 6.11 & 6.07 & 1.05 & 7.19 & 6.99 & 9.53 & 8.27 & 8.00 & 12.1 \\
\hline 8th & 3.90 & 3.95 & 6.81 & 5.22 & 5.07 & 8.26 & 6.14 & 6.14 & 9.71 & 7.14 & 7.06 & 9.34 & 8.34 & 8.05 & 12.4 \\
\hline $\begin{array}{c}\text { Average } \\
\text { (standard } \\
\text { deviation) }\end{array}$ & $\begin{array}{c}3.86 \\
( \pm 0.04)\end{array}$ & $\begin{array}{c}3.87 \\
( \pm 0.08)\end{array}$ & $\begin{array}{c}6.80 \\
( \pm 0.67)\end{array}$ & $\begin{array}{c}5.13 \\
( \pm 0.18)\end{array}$ & $\begin{array}{c}4.97 \\
( \pm 0.11)\end{array}$ & $\begin{array}{c}8.42 \\
( \pm 0.65)\end{array}$ & $\begin{array}{c}6.10 \\
( \pm 0.03)\end{array}$ & $\begin{array}{c}5.96 \\
( \pm 0.15)\end{array}$ & $\begin{array}{c}9.43 \\
( \pm 0.83)\end{array}$ & $\begin{array}{c}7.16 \\
( \pm 0.04)\end{array}$ & $\begin{array}{c}6.93 \\
( \pm 0.11)\end{array}$ & $\begin{array}{c}9.40 \\
( \pm 0.61)\end{array}$ & $\begin{array}{c}8.04 \\
( \pm 0.30)\end{array}$ & $\begin{array}{c}7.99 \\
( \pm 0.05)\end{array}$ & $\begin{array}{c}11.5 \\
( \pm 0.84)\end{array}$ \\
\hline
\end{tabular}




\section{Results}

\subsection{Influx Measurement}

Table 2 summarizes the results of the influx measurement experiments using the Type 1 collection bag. The flux rate without a collection bag represents the reference flow rate at a given head difference controlled by the tank flow system. Our experiments confirmed that the influx rate increased as the water level difference increased. When the experiment was conducted with a collection bag, the sum of the amount of water flowing into the collection bag and the amount of water exiting through the valve on the side the tank was almost the same as the water flux rate as measured without the collection bag. The slope of the trend line between the tank specific fluxes with and without the collection bag was $0.9562\left(R^{2}=0.9751\right.$; as shown in Figure $\left.4 \mathrm{a}\right)$. This suggests that experiments with the collection bag were conducted under nearly the same conditions as those without the collection bag.

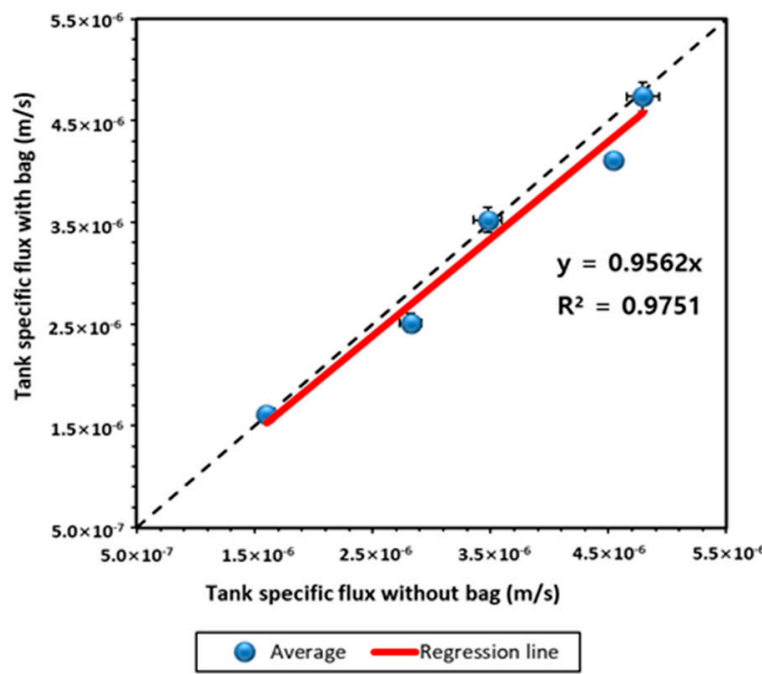

(a)

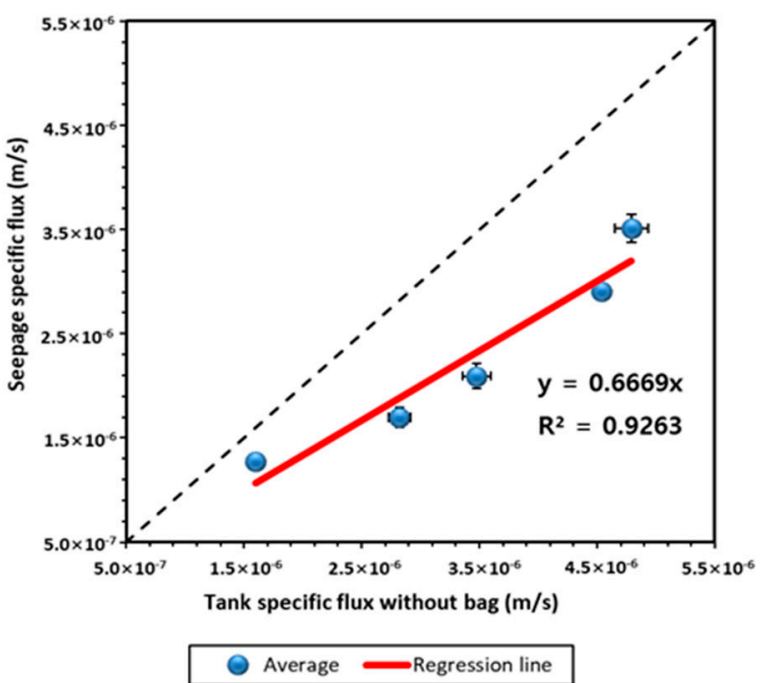

(b)

Figure 4. Comparison of (a) the tank specific influx rates with and without the collection bag and (b) the tank specific influx rate and the seepage specific influx rate measured using the Type 1 collection bag. Error bars represent the standard deviations for five experiments at each head difference (see Table 2).

The influx rate measured by the seepage meter (seepage specific influx) was less than the tank specific influx without the collection bag, which is the controlled flux rate by the tank flow system. The difference between the seepage specific influx and the tank specific influx increased as the head difference increased. The slope between the two flux rates was 0.6669 (Figure $4 \mathrm{~b}$ ), indicating that the influx rate measured by the seepage meter represents around $33 \%$ less than the actual influx rate. As the water level difference increased, the influx rate measured by the seepage meter also increased, indicating a linear relationship between the head difference and the influx rate $\left(R^{2}=0.9263\right.$; as shown in Figure 4b).

Likewise, the influx rate using the Type 2 collection bag was almost the same as that without the collection bag (Table 3). This suggests that these experiments using the Type 2 collection bag were also performed under controlled flow conditions. The slope of the trend line between the tank specific flux rates with and without the collection bag was $0.9968\left(R^{2}=0.9794\right.$; as shown in Figure 5a). 


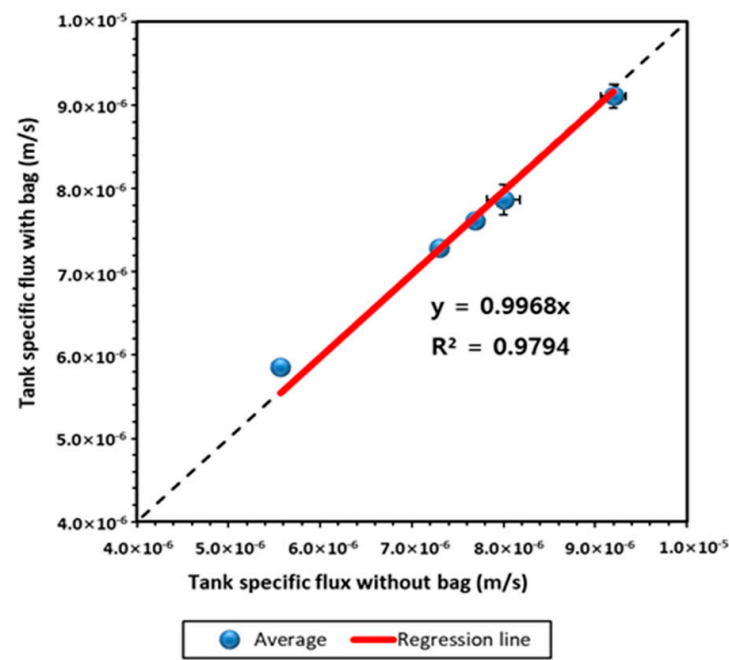

(a)

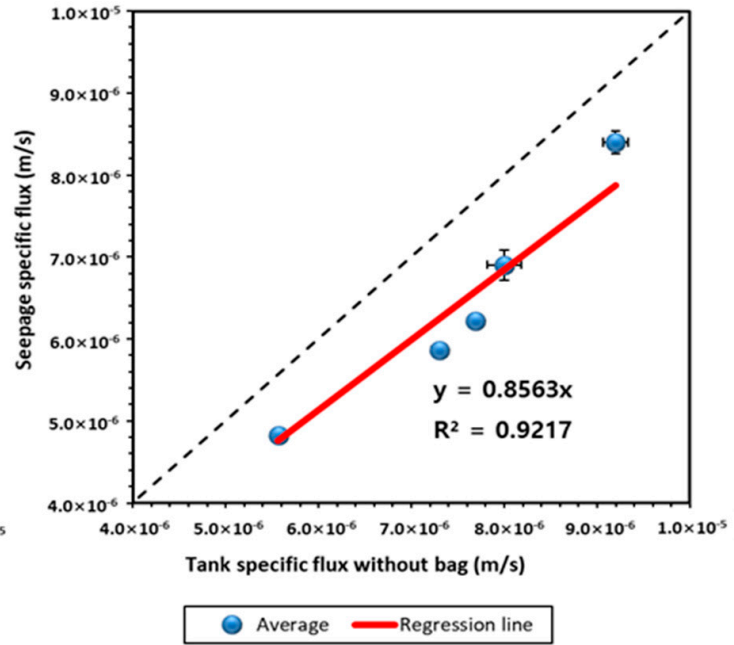

(b)

Figure 5. Comparison of (a) the tank specific influx rates with and without the collection bag and (b) the tank specific influx rate and the seepage specific influx rate measured using the Type 2 collection bag. Error bars represent the standard deviations for five to eight experiments at each head difference (see Table 3).

The slope for the trend line between the seepage specific flux and the tank specific flux was less than 1 . The slope for the trend line with the Type 2 collection bag $(0.8563$; as shown in Figure $5 b)$ was similar but slightly steeper than that of the Type 1 collection bag $(0.6669$; as shown in Figure $4 \mathrm{~b})$. This indicates that influx measurement using the Type 2 collection bag is more accurate than using the Type 1 collection bag. Both collection bags were tested for the influx measurement, and both showed slopes less than 1 . This indicates that when the influx rate of groundwater is measured using the seepage meter, the influx rate measured by the seepage meter can be less than the actual amount of influx.

\subsection{Outflux Measurement}

Table 4 summarizes the results of the outflux measurement experiments using the Type 1 collection bag. The tank specific flux rate prior to installation of the collection bag increased as the pump speed increased. The flux rate after the installation of the collection bag was calculated based on the difference between the initial water volume and the water remaining in the collection bag. The flux rate also increased as pumping speed increased. However, the flux rate measured by the seepage meter was higher than the actual outflux.

The results of the outflux measurement experiments using the Type 1 collection bag were shown in Figure 6. The data points for the tank specific outflux rate with and without the collection bag were close to the 1:1 line. The slope of the trend line was $0.9798\left(R^{2}=0.9817\right.$; as shown in Figure 6a). This indicates that the tank specific outflux rates did not differ much as a consequence of the presence or absence of the collection bag. The flux rate measured using the seepage meter with the Type 1 collection bag were plotted above the 1:1 line. The difference between the seepage specific outflux and the tank specific outflux increased as the pump speed increased. The slope of the trend line was 1.3534 $\left(R^{2}=0.8819\right.$; as shown in Figure $\left.6 b\right)$. This indicates that the outflux rate measured by the seepage meter exceeded the actual outflux rate. 


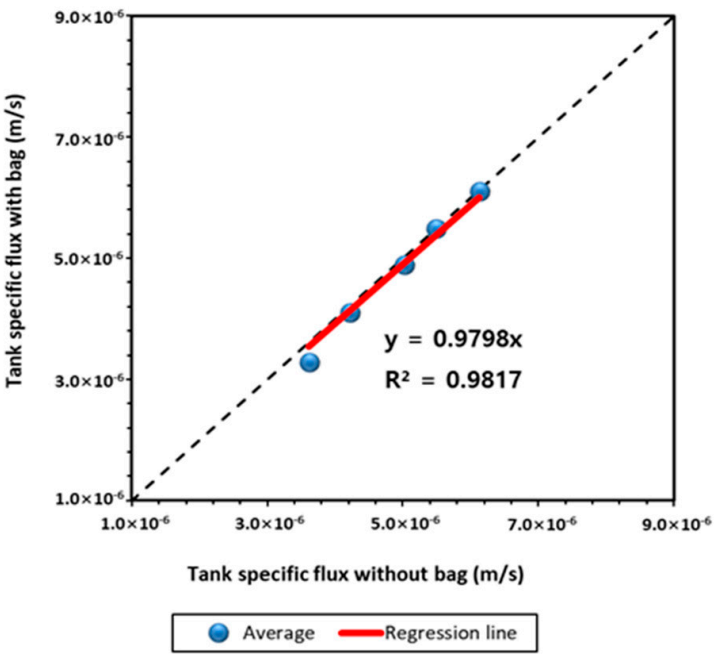

(a)

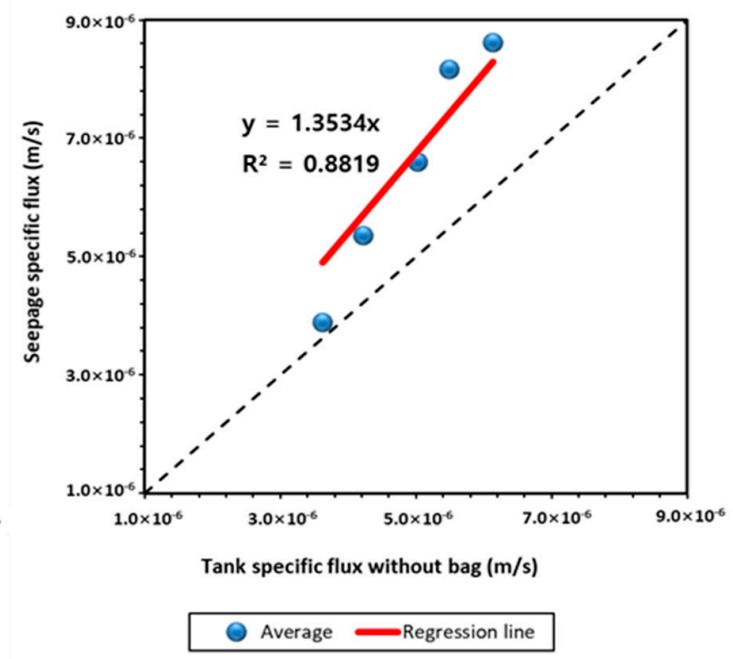

(b)

Figure 6. Comparison of (a) the tank specific outflux rates with and without the collection bag and (b) the tank specific outflux rate and the seepage specific outflux rate measured using the Type 1 collection bag. Error bars represent the standard deviations for five experiments at each pumping rate (see Table 4).

Table 5 summarizes the results of the outflux measurement experiments using the Type 2 collection bag. The tank specific outflux rates with and without the collection bag were similar, suggesting that there was little change in the flux rate through the tank regardless of the presence or absence of the collection bag. The outflux rate measured by the seepage meter was approximately 1.47 times larger than the tank specific flux rate controlled by the tank flow system.

Figure 7 shows the results of the outflux measurement experiments using the Type 2 collection bag. The slope of the trend line between the tank specific outflux rates with and without the collection bag was $0.9813\left(R^{2}=0.9969\right.$; as shown in Figure $\left.7 a\right)$. This indicates that similar flow rates were maintained regardless of the presence or absence of the collection bag. The trend line between the tank specific flux rate without the collection bag and that measured by the seepage meter was 1.4748 (Figure $7 \mathrm{~b}$ ), which is steeper than 1, indicating that the flux rate measured with the Type 2 collection bag can be higher than the actual outflux rate. However, the linearity of the trend line declined substantially $\left(R^{2}=0.6876\right.$; as shown in Figure $7 \mathrm{~b}$ ), suggesting that some experimental artifacts, including the possibility of less-sensitive control of the plump at high speeds and shorter experiment time (10 $\mathrm{min})$ for this portion of the experiment, affected the relationship between the reference flux rate and the rate measured by the seepage meter.

Both collection bags showed steeper slopes than the 1:1 line in the outflux measurement experiments, indicating that when the outflux rate is measured using the seepage meter, the flux rate measured by the seepage meter may be higher than the actual outflux rate. 


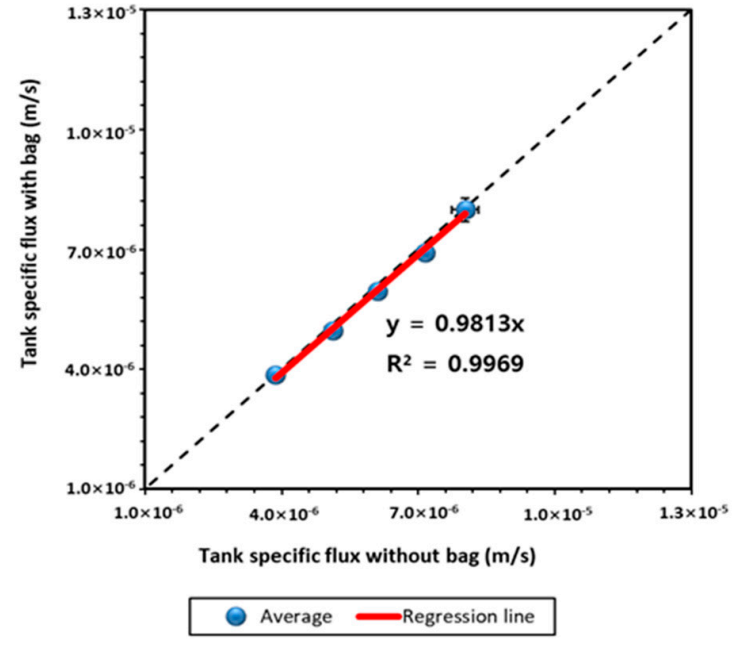

(a)

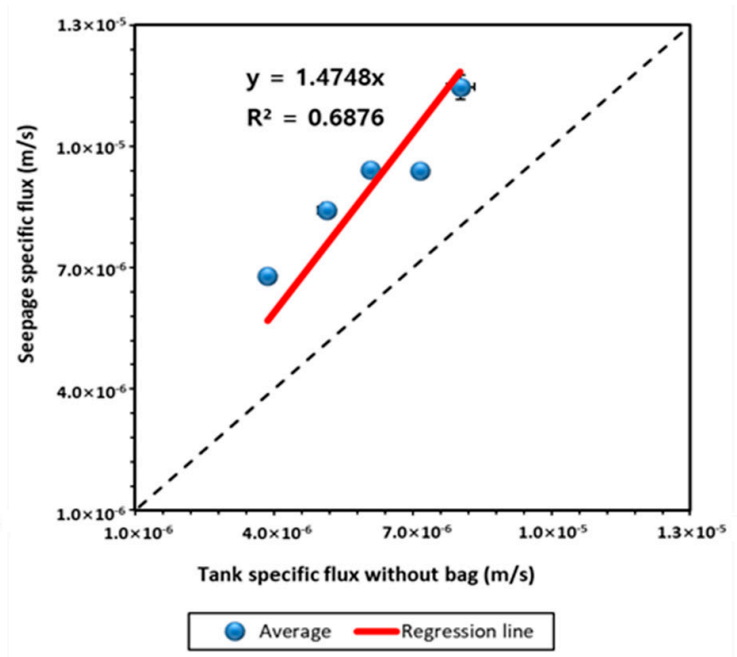

(b)

Figure 7. Comparison of (a) the tank specific outflux rates with and without the collection bag and (b) the tank specific outflux rate and the seepage specific outflux rate measured using the Type 2 collection bag. Error bars represent the standard deviations for eight experiments at each pumping rate (see Table 5).

\section{Discussion}

These experiments were conducted to evaluate whether a seepage meter can accurately measure known fluxes of water and the measured flux rates vary depending on the collection bag connected to the seepage meter. Different types of collection bag (Types 1 and 2) were tested with the same seepage meter and tank flow system. The results of the influx measurement experiments with collection bags were compared with the known fluxes through the tank system (Figures 4 and 5), with the result that the slopes of the trend lines were lower than 1 . This indicates that the influx rate measured using the seepage meter may be lower than the actual influx rate regardless of the type of bag used, at least under these particular experimental conditions. The slope of the trend line was 0.8563 with the Type 2 collection bag, and 0.6669 with the Type 1 collection bag, indicating that the influx rate is closer to the actual value when the Type 2 collection bag is used.

With respect to the outflux measurement experiments, the slopes of the trend lines for the Type 1 and 2 collection bags were both greater than 1 (Figures 6 and 7), indicating that the outflux rate measured by the seepage meter exceeded the actual outflux rate. The slope of the trend line measured with the Type 2 collection bag was 1.4748, which was steeper than of the Type 1 collection bag, which had a slope of 1.3534. This shows that a higher outflux rate can result with the use of the Type 2 collection bag compared to the Type 1 collection bag.

The reason for the lower influx rates measured than actual values is most likely due to the resistance of the collection bags and head loss induced at the tubing orifice [34]. The reason for the higher outflux rates than the actual values is not clear. Lee [20] suggested in his tank experiment that fine clay particles accumulated at the surface of the sediment might control permeability by impeding downward seepage more than upward seepage. In our experiment, however, this may not be the case because we used the homogeneous sieved sand on the top of the sediment layer. It is speculated that an inertial force in the downward direction might accelerate the movement of water in the absence of head loss occurring during the upward movement. Further investigation is required for this issue.

In our experiments, the correction factors, which compensate for measurement inefficiencies, for the influx measurement using the seepage meter were calculated to be 1.49 for the Type 1 collection bag and 1.17 for the Type 2 collection bag. The measurement efficiency is defined as measured flux divided by true flux (the correction factor is the inverse of the efficiency) [19]. In the previous studies, the correction factors for the seepage measurement have been determined for various seepage 
meter designs by comparing seepage rates in a controlled flux tank with seepage rates measured by seepage meters installed in the tank. Typically, seepage meters under-represented the influx seepage rate and the correction factors for the influx measurement have been reported as 1.61 [38], 1.6 [39], 1.43 [40], 1.3 [34], 1.25 [31], 1.11 [41], and 1.05 [42]. However, Rosenberry and Menheer [43] showed that the measured seepage influx can be higher than the controlled flux rate in similarly constructed tanks (correction factors of 0.93 to 1.89). They suggested that this can be the result of an insufficient bag-measurement time, an insufficient number of measurements to average out measurement errors, or the seepage meters being positioned over an area of preferential flow. The field study of Cremeans et al. [29] showed higher correction factors (2 to 3) than those for laboratory calibration studies.

There have been only a few reports on the correction factors for the outflux measurement. Erickson [40] reported the outflux correction factor of 1.74 and Rosenberry and Menheer [43] reported the outflux correction factors of 1.01 to 1.05. In our experiments, the correction factors for the outflux measurement were calculated to be 0.74 for the Type 1 collection bag and 0.68 for the Type 2 collection bag. While we obtained the correction factors for influx and outflux measurements using our seepage meter and collection bags, direct application of these to field studies should be used with caution. Additional effects, such as flowing surface water conditions and layer heterogeneity, should also be considered. The systematic approach in our study conducted in a range of controlled flow rates $\left(1.60\right.$ to $9.20 \times 10^{-6} \mathrm{~m} / \mathrm{s}$ for the influx rate and 3.62 to $8.04 \times 10^{-6} \mathrm{~m} / \mathrm{s}$ for the outflux rate), though, provides a guideline that can be used for field applications.

Zamora [44] tested three different types of collection bag (i.e., shower bags, medical bags, and packaging bags) under constant influx conditions, and showed that flux rates were affected by the size, shape, and wall thickness of the bag, with the result that in general measured seepage influx rates were smaller than known tank influx rates. The relative percent differences (RPDs) between the measured influx rates and the known test tank influx rate were smallest for the packaging bag, which had the thinnest wall thickness. This suggests that if a collection bag is too thick, the volumetric flow into the bag may rapidly decrease as the hydraulic head may not be enough to overcome resistance posed by the increased thickness [44]. Murdoch and Kelly [31] also tested two types of bag: one bag made from thick polyethylene tubing and another from a thinner film of nylon and polyethylene, and showed that the thick-walled bag had highly variable resistance as kinks in the bag were encountered, while the thin-walled bag did not show such features.

In this study, the Type 2 collection bag was larger and slightly thinner than the Type 1 . During the influx measurement experiments, after enough time during which the bags were filled with sufficient water to result in stretching, the flow into the bag might decrease. The Type 2 collection bag might have experienced less interference by stretching due to its bigger size. Also, the slightly thinner wall of the Type 2 bag might result in less resistance than the Type 1 collection bag. These factors would have had the opposite effect during the outflux measurement experiments. With the Type 2 collection bag, water might flow out more easily compared to the Type 1 collection bag.

Previous studies $[31,33,34,44]$ showed that bags performed better when tests started with bags filled with a volume of water prior to their attachment to seepage meters, as compared to empty bags. Empty collection bags at the start of the influx measurement experiment in this study might have affected the influx rates measured by the seepage meter. On the other hand, the size of the seepage meter can affect the measured seepage flux. For example, Rosenberry and Menheer [43] tested two sizes of seepage meter (20.25 cm-diameter and $57 \mathrm{~cm}$-diameter seepage meters). They showed that seepage flux measured with the smaller meters varied by around a factor of two, while larger-diameter seepage meters greatly minimized seepage heterogeneity. Although we did not test the effect of size of the meter, the size of our seepage meter $(58 \mathrm{~cm}$ in diameter) is similar to the larger seepage meter of Rosenberry and Menheer [43]. Thus, it might minimize the spatial heterogeneity by averaging seepage flux over a relatively large area. 


\section{Conclusions}

One important method of understanding the relationship between groundwater and surface water is to use a seepage meter, which directly measures the influx and outflux of groundwater. In our experiments, we tested errors induced by the seepage meter for influx and outflux measurements and compared the differences that arise from the use of different types of collection bags. A simulated groundwater influx/outflux environment was created using a water tank system.

In the influx measurement experiments, the slopes for the trend lines between the tank specific influx rates before and after installing the collection bags were 0.9562 (Type 1) and 0.9968 (Type 2), confirming that our tank flow system worked properly during the measurement period. The influx rates calculated by the seepage meter and the tank specific flux rates were compared, and the slopes of the trend lines were identified as 0.6669 (Type 1) and 0.8563 (Type 2). The influx rate measured using the Type 2 collection bag was closer to the actual value than that with the Type $1 \mathrm{bag}$. This may be because the Type 2 bag is larger and in possession of thinner walls than the Type 1 bag and thus it might experience less resistance compared to the Type 1 bag. Regardless of the type of bag used, the measured influx rates were less than the actual values, most likely due to the resistance of the collection bags and head loss induced at the tubing orifice.

With respect to the outflux measurements, the slopes of the trend lines between the tank specific flux rates with and without collection bags were 0.9798 (Type 1) and 0.9813 (Type 2). This suggests that similar flux rates were maintained by the tank flow system using the pump. When the outflux rates calculated from the seepage meter were compared against the tank specific outflux rates, the slopes of the trend lines were 1.3534 (Type 1) and 1.4748 (Type 2). The outflux rate measured with the Type 1 collection bag was closer to the actual value than that with the Type 2 collection bag. The size and wall thickness of each of the bags might be responsible for the difference in the measured outflux rate. Because both slopes exceeded 1, it is apparent that a higher outflux rate than the actual value may be measured by the seepage meter, regardless of the type of collection bag used. It is speculated that an inertial force in the downward direction might accelerate the movement of water.

This study confirms that the flux rate directly measured using a seepage meter may not represent the actual flux rate. While there were differences in the measured flux rates depending on the types of the bags, measured influx rates were lower than the actual value and outflux rates were higher than the actual value. If the errors generated during measurement can be identified and the causes of such errors can be corrected, groundwater measurement using a seepage meter may evolve to become a more reliable tool for studying interactions between groundwater and surface water. This study was conducted in a simple laboratory setting; thus, application of the results (e.g., correction factors) to field studies should be used with caution. Nonetheless, our systemic approach to evaluate both influx and outflux measurements under the same experimental conditions can serve as a guideline for field applications.

Author Contributions: C.L.: Methodology, Formal analysis, Investigation, Visualization, Writing—original draft preparation; W.K.: Methodology, Formal analysis, Investigation; S.-W.J.: Conceptualization, Writing-review and editing, Supervision, Funding acquisition. All authors have read and agreed to the published version of the manuscript.

Funding: This research was supported by the Polar Academic Program (PE20900) of the Korea Polar Research Institute and by the National Research Foundation of Korea (NRF) grant funded by the Ministry of Science and ICT (NRF-2019R1A2C1086667).

Conflicts of Interest: The authors declare no conflict of interest.

\section{References}

1. Ward, J.V.; Stanford, J.A.; Voelz, N.J. Spatial distribution patterns of Crustacea in the flood plain aquifer of an alluvial river. Hydrobiologia 1994, 287, 11-17. [CrossRef]

2. Brunke, M.; Gonser, T. The ecological significance of exchange processes between rivers and groundwater. Freshw. Boil. 1997, 37, 1-33. [CrossRef] 
3. Silliman, S.E.; Booth, D.F. Analysis of time-series measurements of sediment temperature for identification of gaining vs. losing portions of Juday Creek, Indiana. J. Hydrol. 1993, 146, 131-148. [CrossRef]

4. Winter, T.C.; Harvey, J.W.; Franke, O.L.; Alley, W.M. Ground Water and Surface Water: A Single Resource; U.S. Geological Survey Circular 1139; U.S. Geological Survey: Denver, CO, USA, 1998.

5. Winter, T.C. Relation of streams, lakes, and wetlands to groundwater flow systems. Hydrogeol. J. 1999, 7, 28-45. [CrossRef]

6. Sophocleous, M. Interactions between groundwater and surface water: The state of the science. Hydrogeol. J. 2002, 10, 52-67. [CrossRef]

7. Kalbus, E.; Reinstorf, F.; Schirmer, M. Measuring methods for groundwater-surface water interactions: A review. Hydrol. Earth Syst. Sci. 2006, 10, 873-887. [CrossRef]

8. Jeon, W.-H.; Lee, J.-Y.; Cheong, W.-Y.; Park, Y.-H.; Oh, S.-H.; Eum, D.-H.; Park, J.-Y. A multi-method approach revealing the groundwater-stream water interaction in the Inbuk stream, Korea. Geosci. J. 2015, 19, 325-340. [CrossRef]

9. Barthel, R.; Banzhaf, S. Groundwater and surface water interaction at the regional-scale-A review with focus on regional integrated models. Water Resour. Manag. 2016, 30, 1-32. [CrossRef]

10. Berg, S.J.; Grosso, N.R.; Sherrier, M.P.; Mudrick, K.; Ohr, M.; Hwang, H.-T.; Park, Y.-J.; Callaghan, M.V.; Frey, S.K.; Sudicky, E.A. Natural stimuli calibration with fining direction regularization in an integrated hydrologic model. Ground Water 2019, 57, 21-35. [CrossRef]

11. Constantz, J.; Cox, M.H.; Su, G.W. Comparison of heat and bromide as ground water tracers near streams. Ground Water 2003, 41, 647-656. [CrossRef]

12. Conant, B., Jr. Delineating and quantifying ground water discharge zones using streambed temperatures. Ground Water 2004, 42, 243-257. [CrossRef]

13. Anderson, M.P. Heat as a ground water tracer. Ground Water 2005, 43, 951-968. [CrossRef] [PubMed]

14. Klaus, J.; McDonnell, J.J. Hydrograph separation using stable isotopes: Review and evaluation. J. Hydrol. 2013, 505, 47-64. [CrossRef]

15. Jung, Y.-Y.; Koh, D.-C.; Yoon, Y.-Y.; Kwon, H.-I.; Heo, J.; Ha, K.; Yun, S.-T. Using stable isotopes and tritium to delineate groundwater flow systems and their relationship to streams in the Geum River basin, Korea. J. Hydrol. 2019, 573, 267-280. [CrossRef]

16. Hendricks, S.P. Microbial ecology of the hyporheic zone: A perspective integrating hydrology and biology. J. N. Am. Benthol. Soc. 1993, 12, 70-78. [CrossRef]

17. Lee, J.-H.; Lee, B.-J.; Unno, T. Bacterial communities in ground-and surface water mixing zone induced by seasonal heavy extraction of groundwater. Geomicrobiol. J. 2018, 35, 768-774. [CrossRef]

18. Rautio, A.; Korkka-Niemi, K. Characterization of groundwater-lake water interactions at Pyhäjärvi, a lake in SW Finland. Boreal Environ. Res. 2011, 16, 363-380.

19. Rosenberry, D.O.; Duque, C.; Lee, D.R. History and evolution of seepage meters for quantifying flow between groundwater and surface water: Part 1-Freshwater settings. Earth Sci. Rev. 2020, 204, 103167. [CrossRef]

20. Lee, D.R. A device for measuring seepage flux in lakes and estuaries. Limnol. Oceanogr. 1977, $22,140-147$. [CrossRef]

21. Lee, D.R.; Cherry, J.A. A field exercise on groundwater flow using seepage meters and mini-piezometers. J. Geol. Educ. 1978, 27, 6-10. [CrossRef]

22. Woessner, W.W.; Sullivan, K.E. Results of seepage meter and mini-piezometer study, Lake Mead, Nevada. Ground Water 1984, 22, 561-568. [CrossRef]

23. Isiorho, S.A.; Meyer, J.H. The effects of bag type and meter size on seepage meter measurements. Ground Water 1999, 37, 411-413. [CrossRef]

24. Landon, M.K.; Rus, D.L.; Harvey, F.E. Comparison of instream methods for measuring hydraulic conductivity in sandy streambeds. Ground Water 2001, 39, 870-885. [CrossRef]

25. Rosenberry, D.O.; Morin, R.H. Use of an electromagnetic seepage meter to investigate temporal variability in lake seepage. Ground Water 2004, 42, 68-77. [CrossRef]

26. Rosenberry, D.O. A seepage meter designed for use in flowing water. J. Hydrol. 2008, 359, 118-130. [CrossRef]

27. Jo, I.; Jeen, S.-W. Measurement of groundwater-surface water exchange rates using seepage meters: A case study of Deokjin pond in Jeonju-si (in Korean with English abstract). J. Geol. Soc. Korea 2018, 54, 433-441. [CrossRef] 
28. Lee, C.; Kim, W.; Jeen, S.-W. Analysis of water budget through measurement of groundwater flux using seepage meters at Osongji in Jeonju-si (in Korean with English abstract). J. Geol. Soc. Korea 2019, 55, 461-472. [CrossRef]

29. Cremeans, M.M.; Devlin, J.F.; Osorno, T.C.; McKnight, U.S.; Bjerg, P.L. A comparison of tools and methods for estimating groundwater-surface water exchange. Ground Water Monit. R. 2020, 40, 24-34. [CrossRef]

30. Kim, J.; Jeen, S.-W.; Lim, H.S.; Lee, J.; Kim, O.-S.; Lee, H.; Hong, S.G. Hydrogeological characteristics of groundwater and surface water associated with two small lake systems on King George Island, Antarctica. J. Hydrol. 2020, 590, 125537. [CrossRef]

31. Murdoch, L.C.; Kelly, S.E. Factors affecting the performance of conventional seepage meters. Water Resour. Res. 2003, 39, 1163. [CrossRef]

32. Rosenberry, D.O.; Pitlick, J. Effects of sediment transport and seepage direction on hydraulic properties at the sediment-water interface of hyporheic settings. J. Hydrol. 2009, 373, 377-391. [CrossRef]

33. Shaw, R.D.; Prepas, E.E. Anomalous, short-term influx of water into seepage meters. Limnol. Oceanogr. 1989, 34, 1343-1351. [CrossRef]

34. Belanger, T.V.; Montgomery, M.T. Seepage meter errors. Limnol. Oceanogr. 1992, 37, 1787-1795. [CrossRef]

35. Libelo, E.L.; MacIntyre, W.G. Effects of surface-water movement on seepage-meter measurements of flow through the sediment-water interface. Appl. Hydrogeol. 1994, 2, 49-54. [CrossRef]

36. Kim, J.; Jeen, S.-W.; Lee, J.; Ko, K.-S.; Koh, D.-C.; Kim, W.; Jo, H. Evaluation of temporal contribution of groundwater to a small lake through analyses of water quantity and quality. Water 2020, 12, 2879. [CrossRef]

37. Bedient, P.B.; Huber, W.C.; Vieux, B.E. Hydrology and Floodplain Analysis, 4th ed.; Prentice Hall: Upper Saddle River, NJ, USA, 2008.

38. Dorrance, D.W. Streaming Potential and Seepage Meter Studies at Upper Lake Mary near Flagstaff, Arizona: Tucson. Master's Thesis, University of Arizona, Tucson, AZ, USA, 1989.

39. Cherkauer, D.A.; McBride, J.M. A remotely operated seepage meter for use in large lakes and rivers. Ground Water 1988, 26, 165-171. [CrossRef]

40. Erickson, D.R. A Study of Littoral Groundwater Seepage at Williams Lake, Minnesota using Seepage Meters and Wells. Master's Thesis, University of Minnesota, Minneapolis, MN, USA, 1981.

41. Asbury, C.E. The Role of Groundwater Seepage in Sediment Chemistry and Nutrient Budgets in Mirror Lake, New Hampshire. Ph.D. Thesis, Cornell University, Ithaca, NY, USA, 1990.

42. Rosenberry, D.O. Integrating seepage heterogeneity with the use of ganged seepage meters. Limnol. Oceanogr. Methods 2005, 3, 131-142. [CrossRef]

43. Rosenberry, D.O.; Menheer, M.A. A System for Calibrating Seepage Meters Used to Measure Flow Between Ground Water and Surface Water; USGS Scientific Investigations Report 2006-5053; U.S. Geological Survey: Reston, VA, USA, 2006.

44. Zamora, C. Estimating Water Fluxes across the Sediment-Water Interface in the Lower Merced River, California; USGS Scientific Investigations Report 2007-5216; U.S. Geological Survey: Reston, VA, USA, 2008.

Publisher's Note: MDPI stays neutral with regard to jurisdictional claims in published maps and institutional affiliations.

(C) 2020 by the authors. Licensee MDPI, Basel, Switzerland. This article is an open access article distributed under the terms and conditions of the Creative Commons Attribution (CC BY) license (http://creativecommons.org/licenses/by/4.0/). 